\title{
Are the self-employed really jacks-of-all-trades? Testing the assumptions and implications of Lazear's theory of entrepreneurship with German data*
}

Daniel S. J. Lechmann and Claus Schnabel, University of Erlangen-Nuremberg

Revised version (4 May, 2012)

Abstract: Using a large representative German data set and various concepts of selfemployment, this paper tests the "jack-of-all-trades" view of entrepreneurship by Lazear (AER 2004). Consistent with its theoretical assumptions we find that selfemployed individuals perform more tasks and that their work requires more skills than that of paid employees. In contrast to Lazear's assumptions, however, self-employed individuals do not just need more basic but also more expert skills than employees. Our results also provide only very limited support for the idea that human capital investment patterns differ between those who become self-employed and those ending up in paid employment.

Keywords: entrepreneurship, Germany, jack-of-all-trades, self-employment

New JEL-Classification: L26, J24

\footnotetext{
* For helpful comments and suggestions we would like to thank an anonymous referee of this journal as well as Udo Brixy, Michael Fritsch, Monika Jungbauer-Gans, Joachim Wagner, and participants in economic research seminars at the Universities of Hannover and Erlangen-Nuremberg and in the IECER Conference at Regensburg, 2012.
} 


\section{Introduction}

Although entrepreneurship and self-employment is often associated with high reputation and autonomy, relatively few people choose to become self-employed (whereas many more consider this option): In highly developed countries the rate of self-employment among civilian employment ranges from about 7 percent in the U.S. over 9 percent in France to less than 14 percent in the U.K., with Germany taking a middle position with 12 percent (see Schmitt/Lane 2009, using OECD data for 2007). This scarcity can be regarded as problematic given the prominent role that entrepreneurs are assigned in economics - which can be traced back to Schumpeter (1911) and beyond - and given their importance for economic development and job creation (see, e.g., Parker 2009: chs. 10, 11). It is thus interesting to know why selfemployed individuals are a rare species, what is behind the decision to become selfemployed, and what distinguishes the self-employed from those in paid employment. While there is a vast empirical literature on who becomes self-employed (see, e.g., Blanchflower 2004, and the survey by Parker 2009: chs. 4-6), theoretical analyses of the self-employment decision are less frequent (though not as rare as selfemployment). A recent example that is based on a theoretical model of the choice between paid employment and self-employment and that has quickly obtained a prominent place in the literature is the jack-of-all-trades view of entrepreneurship proposed by Lazear $(2004,2005){ }^{1}$

Lazear (2004: 208) argues that "[e]ntrepreneurs perform many tasks. ... As a consequence, entrepreneurs must be jacks-of-all-trades to some extent. Although they need not be expert in any single skill, they must be sufficiently good at a wide variety to make sure that the business does not fail." A testable implication of this theory is that human capital investment patterns should differ between those who become entrepreneurs and those who end up in paid employment, with individuals with broader, less specialized and more balanced skill sets being more likely to become self-employed.

\footnotetext{
${ }^{1}$ Further theoretical models are provided, e.g., by Lucas (1978), Kihlstrom/Laffont (1979), Kanbur (1979), Murphy/Shleifer/Vishny (1991) and Blanchflower/Oswald (1998); for surveys see de Wit (1993) and Parker (2009: ch. 2).
} 
Lazear's $(2004,2005)$ theory of entrepreneurship, which is at odds with the popular impression that (successful) entrepreneurs are technical specialists, has started an empirical literature attempting to test whether entrepreneurs are really jacks-of-alltrades. By and large, this hypothesis has found some support in a number of international studies that estimated the probability of becoming self-employed for various countries and groups of employees, ranging from Stanford alumni (Lazear 2004, 2005) and Dutch university graduates (Hsieh et al. 2011) over Canadian inventors (Åstebro/Thompson 2011) and U.S. scientists and engineers (Elfenbein et al. 2010) to employees in Switzerland (Backes-Gellner et al. 2010). Partial exceptions are the Finnish study by Hyytinen/llmakunnas (2007), where varied work experience affects entrepreneurial aspirations and transitions to entrepreneurship differently, the study for Italy by Silva (2007) whose results are sensitive to the use of crosssectional or panel data, and the analysis by Hartog et al. (2010) with U.S. panel data, where a more balanced skill set does not affect the probability of becoming selfemployed but positively affects the income of the self-employed. For Germany, Bublitz/Noseleit (2011) also find a positive relationship between balanced skills and income, with returns to balanced skills being larger for entrepreneurs than for employees. One empirical study of employees (Wagner 2003) and three analyses of nascent entrepreneurs (Wagner 2006, Backes-Gellner/Moog 2008 and Stuetzer et al. 2012) further point to the relevance of the jack-of-all-trades theory for Germany whereas two other studies obtain inconclusive results for nascent entrepreneurs (Brixy/Hessels 2010) and for self-employment duration (Oberschachtsiek 2012).

A closer look reveals that the empirical evidence in favor of Lazear's theory is even more limited, and this for at least two reasons: First, most existing studies are based on cross-section data (with the notable exceptions of Silva 2007, Elfenbein et al. 2010, and Hartog et al. 2010) and some prominent studies use relatively few control variables. Second, and more important, the empirical literature has concentrated on analyzing the testable implications of the jacks-of-all-trades theory, but - to the best of our knowledge - the underlying basic assumption by Lazear (2004: 208) that "[e]ntrepreneurs perform many tasks" has never been tested. Even if a theory should not be solely judged by the realism of its assumptions, the case for Lazear's view of entrepreneurship would clearly be strengthened if it could be shown that the work of 
entrepreneurs does indeed require performing many tasks and having a variety of skills.

Taking this research deficit as a starting point, this paper contributes to the literature on the jack-of-all-trades theory of entrepreneurship mainly in three ways: First, we test the fundamental assumption on which Lazear's $(2004,2005)$ theory is based by analyzing whether the number of tasks occurring at work and the number of skills required at work really differ between individuals in (various forms of) selfemployment and in paid employment. Second, we distinguish between basic and expert skills and question whether entrepreneurs really do not need to have expert knowledge of any kind. Third, we provide a further test of the implications of Lazear's theory and analyze the relevance of human capital investment patterns for the probability of being self-employed using a large number of control variables. We are able to perform these exercises since we have a large and representative data set for German employees in 2006 that provides rich information on personal characteristics and on the education and working experience of individuals (including changes of profession), on their (basic or expert) skills required at work, and on their fields of profession, as well as information on regional and firm characteristics. That said, a certain limitation of our study is that this large data set is only cross-sectional, so that unobserved heterogeneity and potential problems of endogeneity cannot be taken into account.

The paper proceeds as follows: Section 2 sketches the theoretical background and derives several hypotheses to be tested. The data and some descriptive evidence are discussed in section 3 . Section 4 tests whether the self-employed really need more skills and perform more tasks than those in paid employment, which by and large seems to be the case in Germany. In section 5, it is analyzed whether the probability of being self-employed is associated with higher numbers of changes of profession and of different kinds of professional training, which finds only limited empirical support. Some concluding remarks are presented in section 6.

\section{Theoretical background and hypotheses}


Lazear $(2004,2005)$ builds his theory on the fundamental assumption that entrepreneurs perform many tasks. Therefore, in order to be successful, they need to have skills in many different areas, i.e. they need to be "jacks-of-all-trades". However, as Lazear points out, entrepreneurs do not have to be experts in any single skill. They can hire workers who specialized in a particular skill and these workers will perform some of the tasks occurring in the firm. Still entrepreneurs need to have at least some basic knowledge of the issues delegated to employees in order to be able, for instance, to give instructions and to make good hiring decisions in the first place. Employees on the other hand do not benefit much from having some basic knowledge in a wide variety of skills. On the contrary, it pays to be as good as possible in the particular area in which tasks are taken over. In Lazear's $(2004,2005)$ theoretical model, the income of employees is determined by their strongest skill whereas the income of entrepreneurs is limited by their weakest skill. Thus entrepreneurs should be generalists whereas employees should be specialists. ${ }^{2}$

As a consequence, the jack-of-all-trades theory of entrepreneurship predicts that individuals who have acquired (basic) knowledge in many different areas have higher probabilities of becoming entrepreneurs than individuals who have acquired (expert) knowledge in just a few if any different areas. Put differently, human capital investment profiles should differ between those individuals who intend to become self-employed entrepreneurs and those who opt for paid employment. Assuming that individuals rationally plan their human capital investment strategies, prospective selfemployed individuals should pursue strategies that lead to the acquisition of the many different skills that are required for being a successful entrepreneur.

Although there is some empirical evidence (sketched above) for the view that individuals who have gained broader experience in different areas are more likely to be entrepreneurs, it should be noted that alternative interpretations of such a relationship are also possible. First, there may be unobserved individual

\footnotetext{
${ }^{2}$ In a modification of the Lazear model Benz (2009) also takes non-monetary benefits into account and thus focuses on overall utility rather than solely on income. While this implies that there will be a positive supply of entrepreneurship even if no profits can be made, it does not change the central prediction that entrepreneurs should be generalists and employees should be specialists.
} 
characteristics that simultaneously lead to a broader skill set and a higher probability of becoming an entrepreneur. Using Italian data, Silva (2007) obtains some evidence that the positive effect of varied experience on the probability of being an entrepreneur found in cross-section studies might be driven by unobserved heterogeneity since it becomes insignificant when applying fixed effect panel techniques. Second, there may be a link between varied experience and the chances of becoming an entrepreneur simply because individuals with greater taste for variety (including taste for job change - the "hobo syndrome") prefer to become entrepreneurs (see Åstebro/Thompson 2011 and the literature cited therein). Åstebro/Thompson (2011) provide some empirical evidence that this may in fact be the case since in their Canadian data a more varied work experience is associated with a lower household income especially among entrepreneurs, which could be interpreted as an indication that individuals with a strong taste for variety are willing to give up income in order to gain variety.

A more fundamental problem is that the research mentioned above only discusses whether the main implication of the jack-of-all-trades theory, namely the positive relationship between varied experience and the likelihood of being an entrepreneur, can actually be observed and how it should be interpreted. What is never being discussed, however, is whether the ideas and assumptions underlying this theory are reasonable and consistent with reality. The premises of Lazear's $(2004,2005)$ theory of entrepreneurship are that entrepreneurs perform many tasks and therefore need many (basic) skills. Investigating whether these assumptions hold is important for at least two reasons: First, if entrepreneurs do not perform many different tasks and do not need to be multi-skilled, Lazear's $(2004,2005)$ theory could be regarded as fundamentally flawed - unless you subscribe to Friedman's (1953) view that the realism of its assumptions is not important for evaluating a theory. Second, if the work of entrepreneurs does not require performing many different tasks and applying many different skills, this would suggest that any observed relationship between entrepreneurship and varied experience might be due to other reasons than the need to acquire broad human capital. 
Taking the assumptions of Lazear $(2004,2005)$ as a starting point of our analysis, we are able to formulate two testable hypotheses: ${ }^{3}$

H1: The number of different tasks occurring at work is higher for entrepreneurs than for employees.

H2: The number of different skills required at work is higher for entrepreneurs than for employees.

Concerning skills, it seems reasonable to distinguish between basic and expert skills. Lazear's $(2004,2005)$ theory implies that entrepreneurs need skills in a variety of areas, but these skills can be rather basic since entrepreneurs can always hire workers to perform tasks that require expert knowledge. In contrast, employees benefit from acquiring expert skills in certain (but few) areas. Therefore we formulate our hypotheses 3 and 4 as follows:

H3: The number of different basic skills required at work is higher for entrepreneurs than for employees.

H4: The number of different expert skills required at work is lower for entrepreneurs than for employees.

While in principle entrepreneurs can hire workers to perform tasks where they lack knowledge, this may depend on how thick the relevant labor market is. In an application of the Lazear model to local labor markets, Helsley/Strange (2011) point out that entrepreneurs need to be generalists to a lesser degree and may still be able to manage successfully if they substitute local market thickness in large cities for a balance of skills. Similarly, certain tasks requiring special or basic skills could be outsourced, but whether this is profitable and feasible depends on transaction costs and on how developed the market infrastructure for complementary services is. This connection to the theory and scope of the firm is not explicitly addressed by Lazear $(2004,2005)$ but may be worth investigating in future research.

Although the assumptions and hypotheses about tasks and skills discussed above have not been checked in the empirical studies testing the jack-of-all-trades view of

\footnotetext{
${ }^{3}$ These hypotheses should not only apply to entrepreneurs in a narrow sense - such as innovators or "founders of a new small restaurant", the example given by Lazear (2004: 208) - but to (almost) all individuals in self-employment. For a more detailed discussion of entrepreneurship and selfemployment, see section 3 .
} 
entrepreneurship, ${ }^{4}$ there is a strand of literature considering task variety in conjunction with work satisfaction. Self-employed are usually found to be more satisfied with their work than employees (see, e.g., Blanchflower 2004). Hundley (2001), for instance, argues that this is in part due to the greater task variety that selfemployed people experience, and he finds empirical support for this notion when analyzing various U.S. surveys. Schjoedt (2009) also states that entrepreneurs engage in many different activities which require them to use different skills. Using a sample of 547 top managers he shows that task variety is significantly higher on average for entrepreneurs than for non-founding managers. These (and similar) studies, however, usually do not analyze task and skill variety as dependent variables but mainly use them for explaining entrepreneurial satisfaction.

A complete test of Lazear's $(2004,2005)$ jack-of-all-trades theory of entrepreneurship of course requires that in addition to the underlying assumptions also the main implication(s) of this theory are investigated empirically. This seems to be particularly useful since some of the extant studies either are based on samples that are barely representative or use a rather limited set of control variables. As described above, the main implication of Lazear's theory is that human capital investment patterns should differ between those who become entrepreneurs and those who end up in paid employment, with individuals with broader, less specialized and more balanced skill sets being more likely to become self-employed. Given our data set explained below and following previous approaches (such as Wagner 2003), this implication can be transformed into the following two hypotheses to be tested: ${ }^{5}$

H5: An individual's probability of being an entrepreneur is higher the larger his number of changes of profession.

\footnotetext{
${ }^{4}$ In a recent study using the same data set but not explicitly designed to test the assumptions of Lazear's theory, Bublitz/Noseleit (2011) also ran regressions with the number of expert skills as the dependent variable, hypothesizing that the number of expert skills is higher for entrepreneurs than for employees (contrary to our hypothesis 4).

${ }^{5}$ Note that this theory also implies a seventh hypothesis, namely that "[i]ndividuals with more balanced skill sets are more likely to become entrepreneurs" (Lazear 2005: 651). Data limitations and the problem of finding a convincing indicator of skill balance preclude us from directly investigating this hypothesis (although the results of testing hypotheses 5 and 6 may provide some indirect evidence). Studies that aim to directly test the balancing hypothesis are Lazear $(2004,2005)$, who uses the extent of special versus general courses of Stanford students, Backes-Gellner/Moog (2008), who construct a composite indicator of relative length of different types of work experience and extend this indicator to include human as well as social capital, and Hartog et al. (2010), who investigate the impact of various cognitive and social abilities.
} 
H6: An individual's probability of being an entrepreneur is higher the larger his number of different kinds of professional training.

In his theoretical model, Lazear (2005) is not very explicit about conditioning, e.g. whether his assumptions and predictions are conditional on an individual working in a particular professional field. That said, he states that the probability of being an entrepreneur may vary by industry due to differences in complexity of production (requiring more different skills and thus reducing the supply of entrepreneurs), which suggests including controls for industry or professional field in the empirical analysis of hypotheses 5 and 6 . He does not discuss whether his assumptions laid down in hypotheses 1 to 4 are based on individuals working in the same professional field but mentions various examples which make clear that the numbers of tasks occurring and of skills required at work vary across professions and industries. In addition, as discussed above, the market infrastructure for complementary inputs and services may differ between professions. Therefore and in order to rule out that it is the kind of work done rather than self-employment which determines tasks and skills it seems sensible to control for the professional fields in which individuals are active in the empirical testing of hypotheses 1 to 4 , too. Nevertheless, we will also conduct robustness checks of estimations without conditioning on the professional fields.

A related question concerns conditioning on firm size, i.e. whether firm size should be included as a control variable. Estimations without controlling for firm size give us the average difference between self-employed persons and those in paid employment whereas estimations including firm size dummies restrict this difference to firms of similar size. In our opinion, the former approach is more in spirit with the theoretical argumentation whereas the latter approach imposes a restriction not postulated by Lazear $(2004,2005)$ and may even be more problematic if firm size has different effects on the tasks and skills of self-employed and paid employees. In particular when looking at the group of self-employed individuals without employees it would be quite inappropriate to just compare these with the special case of employees in firms with one employee. Moreover, firm size could be endogenous if more specialized workers select themselves into bigger firms where the division of labor may be more pronounced. Firm size might also be endogenous for self-employed individuals since 
the model by Lazear (2005: 657f.) predicts that in professional fields with relatively low skill requirements many individuals are able to run their own business so that the number of firms will be high and their average size will be small. For these reasons, we prefer to report the results of regressions without firm size but we will run regressions including ten firm size dummies as a robustness check.

\section{Data and descriptive evidence}

The data set used in this study is the BIBB/BAuA Employment Survey of the Working Population on Qualification and Working Conditions in Germany 2006 (Hall/Tiemann 2006; for a detailed description see Zopf/Tiemann 2010). The data contains information on 20,000 individuals from the German active labor force population (excluding apprentices) who are at least 15 years old and regularly work at least 10 hours per week. The data set is unique in that it does not only include information on self-employment but also provides exceptionally rich information on job characteristics and job and skill requirements which is crucial for our investigation. In contrast, there is almost no information on the latter variables in other large-scale data sets such as the German microcensus (Mikrozensus) or the Regional Entrepreneurship Monitor (REM) Germany. The German Socio-Economic Panel (GSOEP) also provides information on these variables only sporadically and in less detail.

For reasons of data availability and like most of the literature, we use the occupational status of being self-employed as a proxy for entrepreneurship, the theoretical concept applied by Lazear $(2004,2005)$. Of course, self-employment and entrepreneurship may not be exactly the same, not least since the latter is often associated with some sort of innovative activity. However, according to Lazear (2004: 208), this innovative activity "may be as seemingly minor as recognizing that a particular street corner would be a good location for a dry cleaner", and Lazear (2005: 650) acknowledges that there are a number of possible definitions and empirical conceptualizations of entrepreneurship. In his own empirical research, Lazear (2004, 2005: 651) regards "self-employed individuals as entrepreneurs if they 
view themselves as having started a business." However, even if they are not among those who initially started the business, self-employed persons still run their own business and in doing so they should need similar skills as entrepreneurs in a narrower sense (and more skills than employed specialists). Thus the jack-of-alltrades theory should not only apply to entrepreneurs in a narrow sense but also to almost all individuals in self-employment. Still, it seems reasonable to distinguish between self-employed with and without employees (the latter being called solo selfemployed from now on). ${ }^{6}$ Since solo self-employed individuals are not able to delegate tasks to specialized employees they may (have to) be experts in certain areas and have to perform more different tasks than those self-employed who employ others - unless they outsource the activities they cannot delegate. In contrast, the solo self-employed do not need some skills that are important for the owners of larger firms, e.g. concerning personnel management or labor law. Therefore in our analysis we will take into account whether the self-employed also employ others or not.

\section{(Table 1 about here)}

In our data the share of self-employed among all employed individuals is 10.5 percent (see Table 1). This share fits quite well with data obtained from the German microcensus where the share of self-employed amounts to 11.1 percent in 2006 (own calculations). ${ }^{7}$ As Table 1 shows the self-employed can be divided into two groups: tradesmen, who represent the majority of the self-employed, and liberal professionals. This distinction is due to German income tax law which defines liberal professionals (freiberuflich Tätige) as those self-employed who perform scientific, artistic, writing or educational activities or hold jobs like physician, lawyer and tax advisor. Those self-employed who are not members of the liberal professions are called tradesmen in our analysis (and are coded as Selbständige in our data set). Another distinction, which is more important for our analysis, can be made between

\footnotetext{
${ }^{6}$ See also Backes-Gellner et al. (2010) who derive and discuss various definitions of entrepreneurship from Lazear (2005), including self-employment with and without other employees.

${ }^{7}$ Note that our data set does not include apprentices and that we exclude helping family members and freelance collaborators from our analysis since they are neither entrepreneurial nor typical employees. The share calculated from the microcensus data excludes helping family members but includes freelance collaborators and apprentices.
} 
self-employed with and without employees. Table 1 makes clear that a slight majority of business owners have employees but almost one-half run their business as solo self-employed.

Table 2 gives some descriptive evidence on how the self-employed (with and without employees) differ from paid employees: First of all, almost two-thirds of the selfemployed are male, whereas amongst paid employees both sexes are represented equally. This is in line with the stylized fact that men become self-employed much more often than women in Germany (see, e.g., Kelleter 2009) as well as in all developed countries (Parker 2009: 184). The average age and working experience of the self-employed clearly exceed that of paid employees. This is also in line with extant evidence (Parker 2009: 108) and may reflect that the acquisition of diverse experience requires more time than acquiring experience in just one field (assuming that the self-employed in fact need a more diverse skill set). Our data also show that self-employed individuals (in particular those with employees) work considerably more hours per week than paid employees. In contrast, individuals' migration background does not seem to make much of a difference.

(Table 2 about here)

Task variety can be easily analyzed in our data since interviewees were asked how often certain tasks occurred at their work. Altogether there are 17 tasks, examples are "producing goods", "quality control", "purchasing/selling", "advertising/marketing" and "organizing working processes for others". Potential answers are "never", "sometimes" and "often". We measure task variety by counting the number of interviewees' positive statements that a task occurs at work sometimes or often (alternatively we just count tasks occurring often). Table 2 makes clear that the selfemployed have to perform more different tasks at work than employees regardless of whether only tasks that occur often are counted or tasks that occur sometimes or often. The self-employed on average perform 9.6 different tasks sometimes or often whereas employees are only confronted with 8.4 different tasks. 5.7 different tasks occur often at the work of self-employed individuals but only 4.8 in paid employees' jobs. The differences in the numbers of tasks are statistically significant at the 0.1 
percent level in both cases. This descriptive evidence is consistent with hypothesis 1. A closer look shows that these differences exist both for solo self-employed and for self-employed with employees but are considerably higher for the latter.

Information on skill variety is available in our data set since interviewees were asked whether their work required skills in certain areas such as natural scientific skills, technical skills, mercantile/business/economic skills, skills in law or in foreign languages. Potential answers were "no skills", "basic skills", and "expert skills". Following the same approach as in measuring task variety, we count how often (among the 12 different skills given) interviewees state that their work requires basic skills or expert skills (and we also calculate the total number of both skills). The results in Table 2 show that self-employed need more different skills at work than employees, regardless of whether we look at basic skills, expert skills or the total number of skills. On average the work of self-employed requires basic or expert skills in 8.3 different areas whereas the work of employees only requires 6.7 skills. Differences show up both in basic skills (4.8 vs. 4.2 ) and in expert skills (3.5 vs. 2.5 ), and these differences are statistically significant at the 0.1 percent level in all three cases. While these results are consistent with hypotheses 2 and 3 (stating that the number of different skills or of different basic skills required at work should be higher for entrepreneurs than for employees), they are not quite in line with what one would expect according to hypothesis 4 . The self-employed actually seem to need not only more basic but also more expert skills than employees, with the difference in the number of expert skills being even higher (absolutely and relatively) than the difference in the number of basic skills. This holds true for both groups of selfemployed but is again more pronounced for the self-employed with employees.

In addition to information on the tasks individuals perform and on the skills required at work, our data set also contains information in which of 54 professional fields individuals are active (for the classification of the professional fields, see Tiemann et al. 2008). This allows us to take a deeper look at what the self-employed actually do: The largest fraction of the self-employed, namely 11 percent, work in the professional field of management, management consultancy and accounting; here the share of self-employment amounts to 29 percent. The highest self-employment share can be 
found in the professional field of designers, photographers and advertisement manufacturers, where 53 percent of individuals are self-employed. Self-employment is also quite frequent among artists and musicians, among physicians and pharmacists and in agriculture. Concerning tasks occurring at work it is not surprising that 76 percent of the self-employed engage in "advertising/marketing" while the share of employees performing this task is only 39 percent. Similarly 75 percent of the self-employed are active in "purchasing/selling", but this is only true for 44 percent of paid employees. Interestingly self-employed individuals also engage more often in "research/development" than employees (the shares are 46 and 34 percent, respectively), which implies that using self-employment as a proxy for entrepreneurship at least partly captures the innovative activity of entrepreneurs. Concerning skills required at work, the self-employed do not only need more skills on average as reported in Table 2. A closer look at the data reveals that for all 12 skills listed the share of self-employed who need that skill is higher than the share of paid employees who need the same skill. This indicates that the larger overall number of skills required is not due to some single skills that the self-employed need much more often than employees. That said, there is a skill that stands out: mercantile/business/economic skills are reported to be required by 93 percent of the self-employed, whereas only 56 percent of the employees need it.

Exploiting a question in which interviewees were asked how many considerably different professions they have performed in their lifetime, Table 2 further shows that the self-employed have a more varied work experience than employees: While the latter changed their profession only 1.8 times, the self-employed on average report 2.2 changes of profession. This difference, which is statistically significant at the 0.1 percent level, would be consistent with hypothesis 5. A closer look at Table 2 reveals, however, that a substantial difference only shows up for the solo self-employed. On average, the self-employed also had more different kinds of professional training (1.5) than the employed (1.3). While this difference is small, it is again statistically significant at the 0.1 percent level. However, although this descriptive evidence is consistent with hypothesis 6 , it should be taken with a pinch of salt since different kinds of professional training could also reflect a higher level of education rather than just a more diverse one. 
Finally, the last column of Table 2 makes clear that concerning our variables of interest there are marked and statistically significant differences between the selfemployed with and without employees. This suggests once more that empirical analyses should try to distinguish between these two types of self-employment.

\section{Testing the premises of the jack-of-all-trades view of entrepreneurship}

We start our multivariate analysis by testing the assumptions on which Lazear's theory is build, which are laid down in hypotheses 1 to 4 . Hypothesis 1 can be tested by running an OLS regression with the number of tasks occurring at work as the dependent variable and a dummy variable indicating whether an individual is selfemployed as the crucial explanatory variable. ${ }^{8}$

In order to rule out that it is the kind of work individuals do rather than selfemployment that induces the occurrence of many tasks (and the requirement of many skills) we control for several variables which characterize the type of work performed: First of all we include 54 dummies for the professional fields individuals work in (as discussed in section 2). We also take into account that the number of tasks occurring at work may depend on the human capital individuals possess. We thus include the highest level of vocational qualification, the overall working experience (i.e. the number of years since taking up the first job, in linear and quadratic form), the number of years of working intermissions as well as the tenure at the current job (also in years and in linear and quadratic form) as control variables. Since there may occur more different tasks if one just works more hours per week, we also control for working hours (5 dummy variables). Finally, we include sociodemographic control variables such as sex, migration background and place of residence.

\footnotetext{
${ }^{8}$ Note that our empirical results are virtually the same and our insights do not change if we make use of count data models (such as NegBin) rather than OLS in these and the following estimations (results are available from the first author on request). Count data models analyze the number of occurrences of a certain event within a certain interval (of time). We, however, count the number of singular occurrences of different events over uncertain intervals. Therefore, using standard count data methods might be regarded as similarly inappropriate as using OLS, but we are not aware of better ways to analyze our data. For a similar approach using both methods see Bublitz/Noseleit (2011).
} 
(Table 3 about here)

Table 3 presents the results of several OLS regressions of the number of tasks on self-employment, whose explanatory power (in terms of $\mathrm{R}^{2}$ and statistical significance) is quite satisfactory. Despite the large set of control variables, which in most cases conform to expectations, we find a positive relationship between selfemployment and the number of tasks occurring at work. Looking at tasks that occur sometimes or often (column 1), we can see that their number is about 0.78 higher for self-employed individuals than for those in paid employment. If we only focus on tasks that occur often, their average number is by 0.45 higher for the self-employed (column 2). This relationship holds for solo-self employed individuals as well as for those with employees, but the coefficient of the self-employed variable is significantly higher for the latter group (see columns 3 and 4). Since in all estimations the number of different tasks is higher for the self-employed than for those in paid employment, our empirical results support hypothesis 1. However, although the difference is statistically significant at the 1 percent level, it does not seem to be a big number in terms of economic significance. Taking seriously the idea that an entrepreneur has to perform such different tasks as advertising, marketing, innovating, producing goods, collecting information and organizing working processes for others, whereas the employee should specialize in one or just a few of such tasks, the measured average difference of less than one task is smaller than may have been expected.

Given that the self-employed perform more tasks at work, it would not be surprising if their work also required more different skills, as stated in hypothesis 2 . This is tested by estimating OLS regressions of the number of skills required at work on a dummy indicating whether an individual is self-employed and the same control variables included in the regressions concerning the number of tasks above. The estimation results reported in Table 4 indicate that the total number of skills required at work is about 0.64 higher for self-employed individuals than for employees, ceteris paribus, and this effect is again statistically significant at the 1 percent level. The effect is of similar magnitude for the solo self-employed and for those entrepreneurs with 
employees (see columns 4 and 5), and it is statistically significant in both cases. This can be interpreted as a confirmation of hypothesis 2 .

(Table 4 about here)

Since according to Lazear $(2004,2005)$ entrepreneurs' weakest skill determines their success, they should need many basic skills and few expert skills, as formulated in our hypotheses 3 and 4 . The empirical evidence, however, only partly supports these hypotheses. As can be seen from the second column in Table 4, the number of basic skills required at work is indeed higher for self-employed individuals compared to other employees, which is consistent with hypothesis 3. However, while being statistically significant at the 1 percent level, the estimated difference of 0.33 again seems relatively small given that there are 12 skills altogether.

Our fourth hypothesis states that the work of entrepreneurs requires fewer expert skills than the work of paid employees. This hypothesis is soundly rejected by our data. On the contrary, Table 4 shows that the self-employed need 0.31 more expert skills at work than do employees, ceteris paribus, a difference which is statistically significant at the 1 percent level. A similar result is reported by Bublitz/Noseleit (2011) when analyzing 9 rather than 12 skills. This clearly contradicts Lazear's (2004: 208) extreme assumption that "[e]ntrepreneurs...need not be expert in any single skill".

Interestingly, comparing the results in Tables 3 and 4, we see that although business owners with employees perform about one task more than solo self-employed, they need the same amount of (additional) different skills. This casts some doubt on the assumed relationship between tasks and skills, namely that performing more tasks requires more skills. ${ }^{9}$

Taken together, our empirical results allow us to draw an overall picture that is only partly consistent with that sketched by Lazear $(2004,2005)$. We find that the selfemployed indeed perform more tasks than employees and that their work also

\footnotetext{
${ }^{9}$ Note that a simple univariate OLS regression of the number of total skills required on the number of tasks occurring sometimes or often shows that about one-third of the variance in the number of skills can be traced back to the number of tasks.
} 
requires more skills than that of paid employees. In particular the number of basic skills required at work is higher for self-employed individuals. This may be interpreted as supporting hypotheses 1,2 and 3. However, in contrast to Lazear's assumptions (and to hypothesis 4), it is also the number of expert skills required at work (and not just the number of basic skills) which makes a difference between individuals in selfemployment and in paid employment, with self-employed individuals recording more skills of all sorts. ${ }^{10}$

Note that these insights still hold when we perform a number of robustness checks, such as including firm size dummies and thus comparing self-employed individuals and employees in firms of similar size (see the estimation results in the appendix table). We also restricted our sample to individuals aged 18 to 65 , thus excluding the small group of older persons in employment (among whom the self-employed play a more prominent role) and an even smaller group of persons aged 15 to 17 (who are mainly employees). We further re-ran our estimations excluding those (few) individuals who report extreme values of 17 or 0 tasks occurring at work and of 12 or 0 skills required at work. As additional checks of robustness, we replaced our 54 professional fields by 61 branches following the classification of the Federal Statistical Office, we ran our regressions without the field where most self-employed individuals are active in (i.e. management/management consultancy/accounting), we excluded the three professional fields with the highest and the three fields with the lowest rates of self-employment from the sample, and we refrained from conditioning on professional fields and industries. Quantile regressions also show that the relationships between self-employment and the number of tasks occurring sometimes or often and the number of total skills do not vary substantially across the conditional distribution. The results of these robustness checks are not reported in tables but are available on request.

\footnotetext{
${ }^{10}$ One explanation could be that expert skills act as a positive signal to capital lenders so that it makes sense for entrepreneurs to acquire (more) expert skills rather than just basic skills. However, individuals in our survey were explicitly asked about skills required in their current occupation, so that it seems likely that they actually need these expert skills at work and not just as a signal. Another explanation might be that entrepreneurs must have (more) expert skills since the market infrastructure for complementary inputs and services is not well developed, but in a market economy it is quite unlikely that this should occur on a large scale.
} 


\section{Testing the implications of the jack-of-all-trades view of entrepreneurship}

Given that the self-employed do indeed need more skills than employees, the acquisition of these skills may require different human capital investment patterns. Special professional trainings and working in different professions may be one way to acquire the skills needed. Following our hypotheses 5 and 6 we therefore test whether the number of changes of profession and/or the number of different kinds of professional training are related to the probability of being self-employed.

Since we want to analyze the probability of being self-employed, we estimate a probit regression with a dummy indicating self-employment as the dependent variable. We include our two main explanatory variables in a most flexible way by using dummies for different numbers of changes of profession and different kinds of professional training. We control for several variables that have been found to affect the probability of being self-employed in previous studies (see, e.g., Parker 2009: 108 for an overview): These are sex, age (in linear and quadratic form), migration background, disability (3 dummies indicating the level of disability), school-leaving qualification (5 dummies), working experience and intermissions (both also in linear and quadratic form) and family status ( 5 dummies). We again include 54 dummies for the professional fields individuals work in and also 16 regional dummies for their place of residence. Due to data limitations we unfortunately cannot include control variables like parental (entrepreneurial) background or risk aversion and other personality characteristics which also have been found to be determinants of selfemployment (see Caliendo et al. 2011). ${ }^{11}$

(Table 5 about here)

The results of this probit regression, shown in Table 5, are somewhat ambiguous. By and large, the probability of being self-employed seems to rise with the number of changes of profession (column 1). Having changed one's profession once or several times is associated with a higher probability of being self-employed, although the

\footnotetext{
${ }^{11}$ While risk aversion is usually thought to deter individuals from becoming self-employed, Hsieh et al. (2011) argue that individuals with higher risk aversion might want to invest in balanced skills in order to diversify their human capital, making them more likely to become entrepreneurs.
} 
difference becomes statistically significant (at the 5 percent level) only when having changed one's profession twice or more. Three changes of profession are associated with an estimated probability of being self-employed that is 2.5 percentage points higher compared to never having changed the profession. The probability of being self-employed is even 6.3 percentage points higher when having experienced more than five changes of profession.

However, looking at the solo self-employed and at entrepreneurs with employees separately reveals substantial heterogeneity. Columns 2 and 3 of Table 5 indicate that it is only the solo self-employed whose changes of profession are positively and statistically significantly related to the probability of being self-employed. For the sample without solo self-employed individuals, the signs of marginal effects change several times when raising the number of changes of profession and the estimated coefficients are (individually and jointly) not statistically significant at conventional levels. The only exception is having more than five changes of profession which is statistically significant at the 5 percent level and increases the estimated probability of being self-employed by 2.5 percentage points for self-employed individuals with employees.

Furthermore one could argue that the self-employed may be expected to have one more change of profession just because they once changed from paid employment to self-employment (except for those who always have been self-employed). Hence we re-ran the same probit regressions restricting the sample to individuals with at least one change of profession. The results of this robustness check are quite similar in terms of signs and statistical significance of coefficients (except that having changed more than five times is no longer statistically significant for the self-employed with employees).

Thus we find only partial support for our hypothesis 5 that an individual's probability of being an entrepreneur is higher the larger his or her number of changes of profession. While this seems to be true for the solo self-employed it is not the case for entrepreneurs who own larger firms and employ other workers. One possible explanation for this difference could be that individuals with many changes of 
profession are less able to get a stable job in paid employment and thus end up in solo self-employment (whereas managing a firm with other employees is clearly beyond their capacity). Another explanation might be that individuals with a strong taste for variety (reflected in many changes of profession) are likely to end up in solo self-employment but do not want to be stuck in the additional responsibilities which leading a larger firm with employees brings about. In these cases, however, the observed relationship between changes of profession and self-employment would not reflect the human capital investment strategy postulated by Lazear $(2004,2005)$.

Regarding hypothesis 6, the results in Table 5 indicate that there is no clear and robust relationship between the number of different kinds of professional training and the probability of being self-employed. Having completed three different kinds of professional training seems to be associated with an estimated probability of being self-employed that is 3.4 percentage points higher compared to having no professional training (significant at the 1 percent level) but having more or less than three different kinds of training has no statistically significant effect. The same picture emerges for the solo self-employed whereas in the sample without the solo selfemployed having one kind of professional training actually shows an unexpected negative marginal effect, and the other marginal effects are not statistically significant (it should be noted, however, that the numbers of different kinds of professional training are jointly statistically significant at the 1 percent level in all three regressions). Thus we are not able to confirm hypothesis 6 .

Note that our conclusions do not change when performing robustness checks, such as restricting our sample to individuals aged 18 to 65 , excluding the three professional fields with the highest and the three fields with the lowest rates of selfemployment from the sample, replacing our 54 professional fields by 61 branches, applying rare events logit instead of probit estimation, or dividing the self-employed into the two groups defined by German income tax law, namely tradesmen and liberal professionals. The results of these robustness checks are not reported in tables but are available on request. 


\section{Conclusions}

Using a large and representative data set for Germany and various concepts of selfemployment, this paper has tested the assumptions and implications of the "jack-ofall-trades" view of entrepreneurship proposed by Lazear (2004, 2005). Consistent with its theoretical assumptions we find that self-employed individuals perform more tasks than employees and that their work also requires more skills than that of paid employees, although the difference is relatively small. As expected the number of basic skills required at work is higher for self-employed individuals. However, in contrast to Lazear's assumptions (but consistent with recent empirical results by Bublitz/Noseleit 2011), it is also the number of expert skills required at work which makes a difference between individuals in self-employment and in paid employment, with self-employed individuals having more skills of all sorts. This suggests that acquiring broad human capital in the form of many basic skills is not sufficient for becoming self-employed (unlike the Lazear model where entrepreneurs' weakest skill determines their success). Our results make clear that business owners also need more expert skills than employees and that they should be masters of some skills rather than just jacks-of-all-trades.

Testing the implications of Lazear's $(2004,2005)$ theory, we find that an individual's probability of being an entrepreneur is only higher the larger his number of changes of profession if he is solo self-employed (but not if he employs other workers), and that there is no clear and robust relationship between the number of different kinds of professional training and the probability of being self-employed. In contrast to the majority of previous studies for Germany (see, e.g., Wagner 2003, 2006, BackesGellner/Moog 2008) and for other countries (see, e.g., Lazear 2004, 2005, Elfenbein et al. 2010, Backes-Gellner et al. 2010, Hsieh et al. 2011, Åstebro/Thompson 2011) our results thus provide only very limited support for the idea that human capital investment patterns should differ between those who become self-employed and those who end up in paid employment. This implies either that broader and less specialized skill sets are not decisive for becoming self-employed (which would be partly consistent with our results of testing the assumptions) or that modeling human 
capital investment patterns via changes of professions and different kinds of professional training (as done in this and previous studies) is not appropriate.

In addition to scrutinizing the Lazear view of entrepreneurship, our study and its empirical results may also be important for self-employment and entrepreneurship education, both of which have been strongly encouraged by economic policy and by academic organizations in Germany and many other countries. The fact that selfemployed individuals both need more basic and more expert skills than paid employees may explain why relatively few people are able and willing to start their own business. It also suggests that education and training should at the same time be broad and deep and that government agencies should have a closer look at the portfolio of skills of potential entrepreneurs (and possibly provide additional training) before subsidizing start-ups. That said, due to data limitations we have only been able to analyze the tasks and skills of business owners in a cross-section of employees, that is by taking a snapshot view of currently existing self-employed individuals. It would be interesting to know whether owners' basic and expert skills are also relevant for the long-term success and survival of firms and how their portfolio of skills develops over time. This might be a fruitful avenue for further research using panel data. 


\section{References}

Åstebro, T. and P. Thompson (2011), 'Entrepreneurs, Jacks of all trades or Hobos?', Research Policy 40, 637-649.

Backes-Gellner, U., S. N. Tuor and D. Wettstein (2010), 'Differences in the educational paths of entrepreneurs and employees', Empirical Research in Vocational Education and Training 2, 83-105.

Backes-Gellner, U. and P. Moog (2008), 'Who chooses to become an entrepreneur? The Jacks-of-All-Trades in Social and Human Capital', University of Zurich Institute for Strategy and Business Economics Working Paper 76. Zurich.

Benz, M. (2009), 'Entrepreneurship as a non-profit-seeking activity', International Entrepreneurship and Management Journal 5, 23-44.

Blanchflower, D. G. (2004), 'Self-employment: More may not be better', Swedish Economic Policy Review 11, 15-73.

Blanchflower, D. G. and A. J. Oswald (1998), 'What Makes an Entrepreneur?', Journal of Labor Economics 16, 26-60.

Brixy, U. and J. Hessels (2010), 'Human capital and start-up success of nascent entrepreneurs', EIM Research Reports H201013. Zoetermeer.

Bublitz, E. and F. Noseleit (2011), 'The Skill Balancing Act: Determinants of and Returns to Balanced Skills', Jena Economic Research Papers 2011 - 025, Jena.

Caliendo, M., F. Fossen and A. Kritikos (2011), 'Personality Characteristics and the Decision to Become and Stay Self-Employed', IZA Discussion Paper 5566. Bonn.

Elfenbein, D. W., B. H. Hamilton and T. R. Zenger (2010), 'The Small Firm Effect and the Entrepreneurial Spawning of Scientists and Engineers', Management Science $56,659-681$.

Friedman, M. (1953), Essays in positive economics, University of Chicago Press, Chicago, III.

Hall, A. and M. Tiemann (2006), 'BIBB/BAuA Employment Survey of the Working Population on Qualification and Working Conditions in Germany 2006, suf_1.0', Research Data Center at BIBB (ed.), GESIS Cologne, Germany (data access), 
Federal Institute of Vocational Education and Training, Bonn; DOI:

10.4232/1.4820.

Hartog, J., M. van Praag and J. van der Sluis (2010), 'If You Are So Smart, Why Aren't You an Entrepreneur? Returns to Cognitive and Social Ability:

Entrepreneurs Versus Employees', Journal of Economics \& Management Strategy 19, 947-989.

Helsley, R. W. and W. C. Strange (2011), 'Entrepreneurs and cities: Complexity, thickness and balance', Regional Science and Urban Economics 41, 550-559.

Hsieh, C., S. C. Parker and C. M. van Praag (2011), 'Risk, Balanced Skills and Entrepreneurship', IZA Discussion Paper 6200, Bonn.

Hundley, G. (2001), 'Why and When Are the Self-Employed More Satisfied with Their Work?', Industrial Relations 40, 293-316.

Hyytinen, A. and P. Ilmakunnas (2007), 'What distinguishes a serial entrepreneur?', Industrial and Corporate Change 16, 793-821.

Kanbur, S. M. (1979), 'Of Risk Taking and the Personal Distribution of Income', Journal of Political Economy 87, 769-797.

Kelleter, K. (2009), 'Selbstständige in Deutschland. Ergebnisse des Mikrozensus 2008', Wirtschaft und Statistik 12, 1204-1217.

Kihlstrom, R. E. and J.-J. Laffont (1979), 'A General Equilibrium Entrepreneurial Theory of Firm Formation Based on Risk Aversion', Journal of Political Economy 87, 719-748.

Lazear, E. P. (2004), 'Balanced Skills and Entrepreneurship', American Economic Review 94, 208-211.

Lazear, E. P. (2005), 'Entrepreneurship', Journal of Labor Economics 23, 649-680.

Lucas, R. E., Jr. (1978), 'On the Size Distribution of Business Firms', Bell Journal of Economics 9, 508-523.

Murphy, K. M., A. Shleifer and R. W. Vishny (1991), 'The Allocation of Talent: Implications for Growth', Quarterly Journal of Economics 106, 503. 
Oberschachtsiek, D. (2012), 'The experience of the founder and self-employment duration: a comparative advantage approach', Small Business Economics 39, 117.

Parker, S. C. (2009), The economics of entrepreneurship, Cambridge University Press, Cambridge, UK; New York.

Schjoedt, L. (2009), 'Entrepreneurial Job Characteristics: An Examination of Their Effect on Entrepreneurial Satisfaction', Entrepreneurship Theory and Practice 33, 619-644.

Schmitt, J. and N. Lane (2009), 'An International Comparison of Small Business Employment', CEPR Reports and Issue Briefs 2009-27. Washington, DC.

Schumpeter, J. (1911), Theorie der wirtschaftlichen Entwicklung, Duncker \& Humblot, Berlin.

Silva, O. (2007), 'The Jack-of-All-Trades entrepreneur: Innate talent or acquired skill?', Economics Letters 97, 118-123.

Stuetzer, M., M. Obschonka and E. Schmitt-Rodermund (2012), 'Balanced skills among nascent entrepreneurs', Small Business Economics (Online First), DOI: 10.1007/s11187-012-9423-2.

Tiemann, M., H.-J. Schade, R. Helmrich, A. Hall, U. Braun and P. Bott (2008), 'Berufsfeld-Definitionen des BIBB auf Basis der Klassifikation der Berufe 1992', Wissenschaftliche Diskussionspapiere des BIBB 105, Bonn.

Wagner, J. (2003), 'Testing Lazear's jack-of-all-trades view of entrepreneurship with German micro data', Applied Economics Letters 10, 687-689.

Wagner, J. (2006), 'Are nascent entrepreneurs 'Jacks-of-all-trades'? A test of Lazear's theory of entrepreneurship with German data', Applied Economics 38, 2415-2419.

Wit, G. de (1993), 'Models of self-employment in a competitive market', Journal of Economic Surveys 7, 367-397.

Zopf, S. and M. Tiemann (2010), 'BIBB/BAuA-Employment Survey 2005/06', Schmollers Jahrbuch 130, 409-420. 
Table 1: Self-employed and employees according to status

\begin{tabular}{l|rrrr}
\hline & Freq. & Percent & Freq. & Percent \\
\hline Self-employed & 2,071 & 10.5 & & \\
thereof: & & & & \\
$\quad$ Tradesmen & & & 1,611 & 8.2 \\
$\quad$ Liberal professionals & & 460 & 2.3 \\
thereof: & & & \\
$\quad$ Solo self-employed & & 975 & 5.0 \\
Self-employed with employees & & & 1,081 & 5.5 \\
$\quad$ Firm size missing & 17,612 & 89.5 & 15 & 0.1 \\
\hline Employees & & & & \\
thereof: & & & 4,722 & 24.0 \\
$\quad$ Blue-collar workers & & & 11,129 & 56.5 \\
$\quad$ White-collar workers & & & 1,738 & 8.8 \\
Civil servants & & & 23 & 0.1 \\
$\quad$ Blue- or white-collar workers & & & \\
(interviewee cannot decide) & & & 19,683 & 100 \\
\hline Total & 19,683 & 100 & 100 \\
\hline
\end{tabular}

Note: The data set used is the BIBB/BAuA Employment Survey 2006. 
Table 2: Descriptive Statistics

\begin{tabular}{|c|c|c|c|c|c|c|c|c|c|c|}
\hline & \multicolumn{2}{|c|}{ Employees } & \multicolumn{2}{|c|}{ Self-employed } & \multirow{2}{*}{$\begin{array}{c}\text { Difference in } \\
\text { means } \\
\text { (t-test) }\end{array}$} & \multicolumn{2}{|c|}{$\begin{array}{l}\text { Solo self- } \\
\text { employed }\end{array}$} & \multicolumn{2}{|c|}{$\begin{array}{l}\text { Self-employed } \\
\text { with employees }\end{array}$} & \multirow{2}{*}{$\begin{array}{c}\text { Difference in } \\
\text { means } \\
\text { (t-test) }\end{array}$} \\
\hline & Mean & $\begin{array}{l}\text { Std. } \\
\text { dev. }\end{array}$ & Mean & $\begin{array}{l}\text { Std. } \\
\text { dev. }\end{array}$ & & Mean & $\begin{array}{l}\text { Std. } \\
\text { dev. }\end{array}$ & Mean & $\begin{array}{l}\text { Std. } \\
\text { dev. }\end{array}$ & \\
\hline Sex (dummy: female=1) & 0.50 & 0.50 & 0.35 & 0.48 & $0.15^{\star \star}$ & 0.41 & 0.49 & 0.29 & 0.46 & $0.11^{* *}$ \\
\hline Age (in years) & 40.9 & 10.2 & 44.8 & 10.8 & $-3.9^{* *}$ & 44.7 & 11.0 & 44.9 & 10.7 & -0.1 \\
\hline $\begin{array}{l}\text { Migration background } \\
\text { (dummy: yes }=1 \text { ) }\end{array}$ & 0.09 & 0.28 & 0.08 & 0.27 & 0.01 & 0.07 & 0.26 & 0.09 & 0.28 & -0.01 \\
\hline Disability (dummy: yes=1) & 0.07 & 0.25 & 0.05 & 0.21 & $0.02^{* *}$ & 0.06 & 0.23 & 0.04 & 0.19 & $0.02^{*}$ \\
\hline Working hours & 38.4 & 12.0 & 46.4 & 18.8 & $-8.0^{* *}$ & 41.2 & 18.6 & 51.1 & 17.7 & $-9.8^{* *}$ \\
\hline Working experience (in years) & 20.4 & 11.1 & 23.2 & 11.6 & $-2.8^{* *}$ & 23.3 & 11.7 & 23.2 & 11.5 & 0.1 \\
\hline \multicolumn{11}{|l|}{$\begin{array}{l}\text { Number of maximum } 17 \text { tasks } \\
\text { occurring at work }\end{array}$} \\
\hline - sometimes or often & 8.4 & 3.3 & 9.6 & 3.2 & $-1.3^{* \star}$ & 8.8 & 3.0 & 10.5 & 3.2 & $-1.7^{* *}$ \\
\hline - often & 4.8 & 2.6 & 5.7 & 2.7 & $-0.9^{* *}$ & 5.0 & 2.4 & 6.3 & 2.8 & $-1.2^{* *}$ \\
\hline $\begin{array}{l}\text { Number of maximum } 12 \text { skills } \\
\text { required at work }\end{array}$ & & & & & & & & & & \\
\hline - total & 6.7 & 3.0 & 8.3 & 2.5 & $-1.7^{\star \star}$ & 8.0 & 2.5 & 8.6 & 2.5 & $-0.6^{\star *}$ \\
\hline - basic & 4.2 & 2.3 & 4.8 & 2.2 & $-0.6^{\star \star}$ & 4.8 & 2.2 & 4.8 & 2.2 & -0.1 \\
\hline - expert & 2.5 & 2.1 & 3.5 & 2.3 & $-1.0^{* *}$ & 3.3 & 2.2 & 3.8 & 2.3 & $-0.5^{\star *}$ \\
\hline $\begin{array}{l}\text { Number of changes of } \\
\text { profession }\end{array}$ & 1.8 & 1.7 & 2.2 & 2.1 & $-0.3^{\star *}$ & 2.4 & 2.1 & 1.9 & 2.0 & $0.5^{\star \star}$ \\
\hline $\begin{array}{l}\text { Number of different kinds of } \\
\text { professional training }\end{array}$ & 1.3 & 0.8 & 1.5 & 0.9 & $-0.2^{\star \star}$ & 1.5 & 0.9 & 1.6 & 0.9 & -0.02 \\
\hline
\end{tabular}

Notes: The data set used is the BIBB/BAuA Employment Survey 2006. ${ }^{* * *}$ indicates statistical significance at the 5/1\% level. 
Table 3: OLS estimates for the number of tasks occurring at work

\begin{tabular}{|c|c|c|c|c|}
\hline & \multicolumn{4}{|c|}{ Number of maximum 17 tasks that occur at work } \\
\hline & $\begin{array}{l}\text { sometimes } \\
\text { or often }\end{array}$ & often & $\begin{array}{l}\text { sometimes } \\
\text { or often } \\
\text { only solo } \\
\text { self- } \\
\text { employed }\end{array}$ & $\begin{array}{l}\text { sometimes } \\
\text { or often } \\
\text { without } \\
\text { solo self- } \\
\text { employed }\end{array}$ \\
\hline $\begin{array}{l}\text { Self-employed } \\
\text { (dummy: yes=1) }\end{array}$ & $\begin{array}{l}0.784^{* *} \\
(0.076) \\
\end{array}$ & $\begin{array}{l}0.450^{* \star} \\
(0.064)\end{array}$ & $\begin{array}{l}0.269^{* *} \\
(0.100)\end{array}$ & $\begin{array}{l}1.280^{* *} \\
(0.102)\end{array}$ \\
\hline $\begin{array}{l}\text { Sex } \\
\text { (dummy: female=1) }\end{array}$ & $\begin{array}{l}-0.469^{* \star} \\
(0.054)\end{array}$ & $\begin{array}{l}-0.090^{*} \\
(0.042)\end{array}$ & $\begin{array}{l}-0.525^{\star *} \\
(0.056)\end{array}$ & $\begin{array}{l}-0.479^{\star \star} \\
(0.056)\end{array}$ \\
\hline $\begin{array}{l}\text { Migration background } \\
\text { (dummy: yes=1) }\end{array}$ & $\begin{array}{l}-0.084 \\
(0.079)\end{array}$ & $\begin{array}{l}0.145^{\star} \\
(0.066)\end{array}$ & $\begin{array}{l}-0.076 \\
(0.082)\end{array}$ & $\begin{array}{l}-0.059 \\
(0.081)\end{array}$ \\
\hline $\begin{array}{l}\text { Highest vocational degree } \\
\text { (reference: no vocational } \\
\text { qualification): }\end{array}$ & & & & \\
\hline $\begin{array}{l}\text { Vocational training } \\
\text { (dummy: yes=1) }\end{array}$ & $\begin{array}{l}0.506^{* *} \\
(0.087)\end{array}$ & $\begin{array}{l}0.339^{* *} \\
(0.068)\end{array}$ & $\begin{array}{l}0.537^{\star *} \\
(0.089)\end{array}$ & $\begin{array}{l}0.539^{\star \star} \\
(0.089)\end{array}$ \\
\hline $\begin{array}{l}\text { Vocational college } \\
\text { (dummv: ves=1) }\end{array}$ & $\begin{array}{l}1.405^{* *} \\
(0.118)\end{array}$ & $\begin{array}{l}0.988^{* *} \\
(0.096)\end{array}$ & $\begin{array}{l}1.389^{* *} \\
(0.123)\end{array}$ & $\begin{array}{l}1.414^{* *} \\
(0.122)\end{array}$ \\
\hline $\begin{array}{l}\text { University or } \\
\text { university of applied science } \\
\text { (dummy: yes }=1 \text { ) }\end{array}$ & $\begin{array}{c}0.243^{*} \\
(0.098)\end{array}$ & $\begin{array}{l}0.242^{* *} \\
(0.077)\end{array}$ & $\begin{array}{r}0.234^{*} \\
(0.101)\end{array}$ & $\begin{array}{l}0.275^{\star \star} \\
(0.102)\end{array}$ \\
\hline $\begin{array}{l}\text { Working experience } \\
\text { (in vears) }\end{array}$ & $\begin{array}{l}0.015^{*} \\
(0.007)\end{array}$ & $\begin{array}{l}0.017^{* *} \\
(0.006)\end{array}$ & $\begin{aligned} 0.016^{*} \\
(0.008)\end{aligned}$ & $\begin{array}{l}0.016^{*} \\
(0.008)\end{array}$ \\
\hline Working experience squared & $\begin{array}{l}-0.001^{* *} \\
(0.000)\end{array}$ & $\begin{array}{l}-0.001^{* *} \\
(0.000)\end{array}$ & $\begin{array}{l}-0.001^{* *} \\
(0.000)\end{array}$ & $\begin{array}{l}-0.001^{* *} \\
(0.000)\end{array}$ \\
\hline $\begin{array}{l}\text { Working intermissions } \\
\text { (in years) }\end{array}$ & $\begin{array}{l}0.012 \\
(0.014)\end{array}$ & $\begin{array}{l}0.003 \\
(0.011)\end{array}$ & $\begin{array}{c}0.015 \\
(0.014)\end{array}$ & $\begin{array}{c}0.016 \\
(0.014)\end{array}$ \\
\hline $\begin{array}{l}\text { Working intermissions } \\
\text { squared }\end{array}$ & $\begin{array}{l}-0.001 \\
(0.001)\end{array}$ & $\begin{array}{l}-0.001 \\
(0.001)\end{array}$ & $\begin{array}{l}-0.002^{*} \\
(0.001)\end{array}$ & $\begin{array}{l}-0.002^{*} \\
(0.001)\end{array}$ \\
\hline $\begin{array}{l}\text { Tenure at current job } \\
\text { (in vears) }\end{array}$ & $\begin{array}{l}0.052^{* *} \\
(0008)\end{array}$ & $\begin{array}{l}0.029^{* *} \\
(0006)\end{array}$ & $\begin{array}{l}0.051^{* *} \\
(0008)\end{array}$ & $\begin{array}{l}0.053^{* *} \\
(0008)\end{array}$ \\
\hline $\begin{array}{l}\text { Tenure at current job } \\
\text { squared }\end{array}$ & $\begin{array}{l}-0.001^{* *} \\
(0.000)\end{array}$ & $\begin{array}{l}-0.001^{* *} \\
(0.000)\end{array}$ & $\begin{array}{l}-0.001^{* *} \\
(0.000)\end{array}$ & $\begin{array}{l}-0.001^{* *} \\
(0.000)\end{array}$ \\
\hline $\begin{array}{l}\text { Working hours } \\
\text { ( } 5 \text { dummies) }\end{array}$ & Yes $^{* *}$ & Yes $^{* \star}$ & Yes $^{* *}$ & Yes $^{* *}$ \\
\hline $\begin{array}{l}\text { Place of residence } \\
\text { (16 "Bundesländer" dummies) }\end{array}$ & Yes & Yes $^{\star \star}$ & Yes & Yes \\
\hline $\begin{array}{l}\text { Professional field } \\
\text { (54 dummies) }\end{array}$ & Yes $^{* *}$ & Yes $^{* *}$ & Yes $^{* *}$ & Yes $^{* *}$ \\
\hline Constant & $\begin{array}{l}9.534^{\star *} \\
(0.243)\end{array}$ & $\begin{array}{l}4.550^{* *} \\
(0.217)\end{array}$ & $\begin{array}{l}9.149^{* \star} \\
(0.268)\end{array}$ & $\begin{array}{l}9.283^{\star *} \\
(0.258)\end{array}$ \\
\hline $\begin{array}{l}\text { Number of observat } \\
R^{2}\end{array}$ & $\begin{array}{c}18,990 \\
0.28\end{array}$ & $\begin{array}{c}18,990 \\
0.24\end{array}$ & $\begin{array}{c}17,920 \\
0.27\end{array}$ & $\begin{array}{c}18,042 \\
0.29\end{array}$ \\
\hline
\end{tabular}

Notes: The data set used is the BIBB/BAuA Employment Survey 2006. Robust standard errors in brackets. ${ }^{* * *}$ indicates statistical significance at the $5 / 1 \%$ level. 
Table 4: OLS estimates for the number of skills required at work

\begin{tabular}{|c|c|c|c|c|c|}
\hline & \multicolumn{5}{|c|}{ Number of maximum 12 skills that are required at work } \\
\hline & total skills & $\begin{array}{l}\text { basic } \\
\text { skills }\end{array}$ & $\begin{array}{l}\text { expert } \\
\text { skills }\end{array}$ & $\begin{array}{l}\text { total skills } \\
\text { solo self- } \\
\text { employed }\end{array}$ & $\begin{array}{l}\text { total skills } \\
\text { without } \\
\text { solo self- } \\
\text { employed }\end{array}$ \\
\hline $\begin{array}{l}\text { Self-employed } \\
\text { (dummy: yes=1) }\end{array}$ & $\begin{array}{l}0.642^{\star \star} \\
(0.062)\end{array}$ & $\begin{array}{l}0.328^{* *} \\
(0.058)\end{array}$ & $\begin{array}{l}0.314^{* *} \\
(0.053)\end{array}$ & $\begin{array}{l}0.633^{\star *} \\
(0.085)\end{array}$ & $\begin{array}{l}0.625^{\star \star} \\
(0.082)\end{array}$ \\
\hline $\begin{array}{l}\text { Sex } \\
\text { (dummy: female=1) }\end{array}$ & $\begin{array}{l}-0.846^{\star \star} \\
(0.045)\end{array}$ & $\begin{array}{l}-0.388^{* *} \\
(0.040)\end{array}$ & $\begin{array}{l}-0.458^{* *} \\
(0.034)\end{array}$ & $\begin{array}{l}-0.878^{* \star} \\
(0.047)\end{array}$ & $\begin{array}{l}-0.862^{\star \star} \\
(0.047)\end{array}$ \\
\hline $\begin{array}{l}\text { Migration background } \\
\text { (dummy: yes=1) }\end{array}$ & $\begin{array}{l}-0.110 \\
(0.067)\end{array}$ & $\begin{array}{l}-0.131^{*} \\
(0.059)\end{array}$ & $\begin{array}{c}0.020 \\
(0.049)\end{array}$ & $\begin{array}{l}-0.096 \\
(0.069)\end{array}$ & $\begin{array}{l}-0.102 \\
(0.068)\end{array}$ \\
\hline $\begin{array}{l}\text { Highest vocational degree } \\
\text { (reference: no vocational } \\
\text { qualification): }\end{array}$ & & & & & \\
\hline $\begin{array}{l}\text { l training } \\
e s=1)\end{array}$ & $\begin{array}{l}0.631^{* *} \\
(0.077)\end{array}$ & $\begin{array}{l}0.241^{* *} \\
(0.065)\end{array}$ & $\begin{array}{l}0.390^{* *} \\
(0.048)\end{array}$ & $\begin{array}{l}0.657^{* *} \\
(0.078)\end{array}$ & $\begin{array}{l}0.643^{\star *} \\
(0.079)\end{array}$ \\
\hline $\begin{array}{l}\text { Vocational college } \\
\text { (dummy: yes=1) }\end{array}$ & $\begin{array}{l}1.907^{* *} \\
(0.099)\end{array}$ & $\begin{array}{l}0.665^{* *} \\
(0.087)\end{array}$ & $\begin{array}{l}1.242^{* *} \\
(0.075)\end{array}$ & $\begin{array}{l}1.970^{* *} \\
(0.103)\end{array}$ & $\begin{array}{l}1.904^{* *} \\
(0.103)\end{array}$ \\
\hline $\begin{array}{l}\text { University or } \\
\text { university of applied science } \\
\text { (dummy: yes=1) }\end{array}$ & $\begin{array}{l}1.457^{* *} \\
(0.086)\end{array}$ & $\begin{array}{l}0.287^{* *} \\
(0.073)\end{array}$ & $\begin{array}{l}1.170^{* *} \\
(0.059)\end{array}$ & $\begin{array}{l}1.485^{* *} \\
(0.088)\end{array}$ & $\begin{array}{l}1.487^{* *} \\
(0.089)\end{array}$ \\
\hline $\begin{array}{l}\text { Working experience } \\
\text { (in years) }\end{array}$ & $\begin{array}{l}0.028^{* *} \\
(0.006)\end{array}$ & $\begin{array}{l}0.021^{* *} \\
(0.006)\end{array}$ & $\begin{array}{c}0.008 \\
(0.005)\end{array}$ & $\begin{array}{l}0.028^{\star *} \\
(0.006)\end{array}$ & $\begin{array}{l}0.030^{\star \star} \\
(0.006)\end{array}$ \\
\hline Working experience squared & $\begin{array}{l}-0.001^{* *} \\
(0.000)\end{array}$ & $\begin{array}{l}-0.001^{* *} \\
(0.000)\end{array}$ & $\begin{array}{l}-0.000^{*} \\
(0.000)\end{array}$ & $\begin{array}{l}-0.001^{* *} \\
(0.000)\end{array}$ & $\begin{array}{l}-0.001^{\star *} \\
(0.000)\end{array}$ \\
\hline $\begin{array}{l}\text { Working intermissions } \\
\text { (in years) }\end{array}$ & $\begin{array}{l}-0.006 \\
(0.013)\end{array}$ & $\begin{array}{l}0.016 \\
(0.011)\end{array}$ & $\begin{array}{l}-0.022^{* *} \\
(0.008)\end{array}$ & $\begin{array}{l}-0.003 \\
(0.013)\end{array}$ & $\begin{array}{l}-0.006 \\
(0.013)\end{array}$ \\
\hline $\begin{array}{l}\text { Working intermissions } \\
\text { squared }\end{array}$ & $\begin{array}{l}-0.001 \\
(0.001)\end{array}$ & $\begin{array}{l}-0.001 \\
(0.001)\end{array}$ & $\begin{array}{c}0.000 \\
(0.000)\end{array}$ & $\begin{array}{l}-0.001 \\
(0.001)\end{array}$ & $\begin{array}{l}-0.001 \\
(0.001)\end{array}$ \\
\hline $\begin{array}{l}\text { Tenure at current job } \\
\text { (in years) }\end{array}$ & $\begin{array}{l}0.013^{*} \\
(0.007)\end{array}$ & $\begin{array}{l}0.009 \\
(0.006)\end{array}$ & $\begin{array}{l}0.004 \\
(0.005)\end{array}$ & $\begin{array}{c}0.012 \\
(0.007)\end{array}$ & $\begin{array}{l}0.018^{* \star} \\
(0.007)\end{array}$ \\
\hline $\begin{array}{l}\text { Tenure at current job } \\
\text { squared }\end{array}$ & $\begin{array}{l}-0.000 \\
(0.000)\end{array}$ & $\begin{array}{l}-0.000 \\
(0.000)\end{array}$ & $\begin{array}{l}-0.000 \\
(0.000)\end{array}$ & $\begin{array}{l}-0.000 \\
(0.000)\end{array}$ & $\begin{array}{l}-0.000 \\
(0.000)\end{array}$ \\
\hline $\begin{array}{l}\text { Working hours } \\
\text { ( } 5 \text { dummies) }\end{array}$ & Yes $^{* *}$ & Yes $^{* *}$ & Yes $^{\star *}$ & Yes $^{* *}$ & Yes $^{* *}$ \\
\hline $\begin{array}{l}\text { Place of residence } \\
\text { (16 "Bundesländer" dummies) }\end{array}$ & Yes $^{*}$ & Yes $^{\star *}$ & Yes $^{\star *}$ & Yes & Yes $^{*}$ \\
\hline $\begin{array}{l}\text { Professional field } \\
\text { (54 dummies) }\end{array}$ & Yes $^{\star \star}$ & Yes $^{\star \star}$ & Yes $^{\star *}$ & Yes $^{\star \star}$ & Yes $^{\star *}$ \\
\hline Constant & $\begin{array}{l}6.598^{\star \star} \\
(0.200)\end{array}$ & $\begin{array}{l}4.321^{* *} \\
(0.172)\end{array}$ & $\begin{array}{l}2.277^{\star *} \\
(0.161)\end{array}$ & $\begin{array}{l}6.479^{* *} \\
(0.224)\end{array}$ & $\begin{array}{l}6.457^{* \star} \\
(0.211)\end{array}$ \\
\hline $\begin{array}{l}\text { Num } \\
R^{2}\end{array}$ & $\begin{array}{c}18,974 \\
0.37\end{array}$ & $\begin{array}{c}18,974 \\
0.13\end{array}$ & $\begin{array}{c}18,974 \\
0.32\end{array}$ & $\begin{array}{l}17,908 \\
0.37\end{array}$ & $\begin{array}{c}18,023 \\
0.38\end{array}$ \\
\hline
\end{tabular}

Notes: The data set used is the BIBB/BAuA Employment Survey 2006. Robust standard errors in brackets. ${ }^{* * *}$ indicates statistical significance at the $5 / 1 \%$ level. 
Table 5: Probit estimates for the probability of being self-employed: average partial effects

\begin{tabular}{|c|c|c|c|}
\hline Self-employed in the sample & all & $\begin{array}{l}\text { only solo self- } \\
\text { employed }\end{array}$ & $\begin{array}{l}\text { without solo } \\
\text { self-employed }\end{array}$ \\
\hline \multicolumn{4}{|l|}{$\begin{array}{l}\text { Number of changes of profession } \\
\text { (reference: no change) }\end{array}$} \\
\hline $\begin{array}{l}\text { One change } \\
\text { (dummy: yes=1) }\end{array}$ & $\begin{array}{c}0.008 \\
(0.006)\end{array}$ & $\begin{array}{c}0.008 \\
(0.005)\end{array}$ & $\begin{array}{c}0.004 \\
(0.005)\end{array}$ \\
\hline Two changes & $0.014^{*}$ & $0.019^{* *}$ & -0.001 \\
\hline (dummy: yes=1) & $(0.006)$ & $(0.005)$ & $(0.005)$ \\
\hline $\begin{array}{l}\text { Three changes } \\
\text { (dummy: yes=1) }\end{array}$ & $\begin{array}{l}0.025^{\star *} \\
(0.007)\end{array}$ & $\begin{array}{l}0.034^{* *} \\
(0.006)\end{array}$ & $\begin{array}{l}-0.003 \\
(0.006)\end{array}$ \\
\hline $\begin{array}{l}\text { Four changes } \\
\text { (dummv:ves }=1 \text { ) }\end{array}$ & $0.048^{* *}$ & $\begin{array}{l}0.050^{* *} \\
(0.009)\end{array}$ & $\begin{array}{l}0.007 \\
(0.008)\end{array}$ \\
\hline Five changes & $0.044^{* *}$ & $0.054^{\star *}$ & $\begin{array}{l}-0.003) \\
-0.003\end{array}$ \\
\hline (dummy: yes=1) & $(0.013)$ & $(0.012)$ & $(0.010)$ \\
\hline $\begin{array}{l}\text { More than five changes } \\
\text { (dummy: ves=1) }\end{array}$ & $\begin{array}{l}0.063^{* *} \\
(0.015)\end{array}$ & $\begin{array}{l}0.055^{\star *} \\
(0.014)\end{array}$ & $\begin{array}{l}0.025^{*} \\
(0.013)\end{array}$ \\
\hline \multicolumn{4}{|l|}{$\begin{array}{l}\text { Number of different kinds of } \\
\text { professional training } \\
\text { (reference: no professional training) }\end{array}$} \\
\hline $\begin{array}{l}\text { One kind } \\
\text { (dummy: yes=1) }\end{array}$ & $\begin{array}{l}-0.016 \\
(0.009)\end{array}$ & $\begin{array}{l}-0.001 \\
(0.007)\end{array}$ & $\begin{array}{l}-0.018^{*} \\
(0.008)\end{array}$ \\
\hline $\begin{array}{l}\text { Two kinds } \\
\text { (dummy: ves=1) }\end{array}$ & $\begin{array}{l}0.006 \\
(0.010)\end{array}$ & $\begin{array}{c}0.009 \\
(0.008)\end{array}$ & $\begin{array}{l}-0.001 \\
(0.009)\end{array}$ \\
\hline $\begin{array}{l}\text { Three kinds } \\
(d u m m v \cdot v e s=1)\end{array}$ & $0.034^{* *}$ & $0.024^{*}$ & 0.018 \\
\hline More than three kinds & $\begin{array}{c}(0.013) \\
0.016\end{array}$ & $\begin{array}{l}(0.010) \\
0.017\end{array}$ & $\begin{array}{c}(0.011) \\
0.001\end{array}$ \\
\hline (dummy: yes=1) & $(0.020)$ & $(0.016)$ & $(0.017)$ \\
\hline $\begin{array}{l}\text { Sex } \\
\text { (dummy: female=1) }\end{array}$ & $\begin{array}{l}-0.045^{\star *} \\
(0.005)\end{array}$ & $\begin{array}{l}-0.014^{\star *} \\
(0.004)\end{array}$ & $\begin{array}{l}-0.039^{* *} \\
(0.004)\end{array}$ \\
\hline $\begin{array}{l}\text { Age } \\
\text { (in years, linear and squared) }\end{array}$ & $\begin{array}{l}0.004^{* *} \\
(0.001)\end{array}$ & $\begin{array}{l}0.003^{* *} \\
(0.001)\end{array}$ & $\begin{array}{l}0.002^{* *} \\
(0.001)\end{array}$ \\
\hline $\begin{array}{l}\text { Migration background } \\
\text { (dummy: yes=1) }\end{array}$ & $\begin{array}{l}-0.001 \\
(0.008)\end{array}$ & $\begin{array}{l}-0.004 \\
(0.006)\end{array}$ & $\begin{array}{c}0.006 \\
(0.007) \\
\end{array}$ \\
\hline \multicolumn{4}{|l|}{$\begin{array}{l}\text { Level of disability (reference: no } \\
\text { disability) }\end{array}$} \\
\hline $\begin{array}{l}\text { Less than } 50 \% \\
\text { (dummy: yes=1) }\end{array}$ & $\begin{array}{l}-0.040^{* *} \\
(0.010)\end{array}$ & $\begin{array}{l}-0.017^{*} \\
(0.008)\end{array}$ & $\begin{array}{l}-0.031^{* *} \\
(0.007)\end{array}$ \\
\hline $\begin{array}{l}\text { More than } 50 \% \\
\text { (dummy: yes=1) }\end{array}$ & $\begin{array}{l}-0.021 \\
(0.012)\end{array}$ & $\begin{array}{l}-0.005 \\
(0.010)\end{array}$ & $\begin{array}{l}-0.019^{*} \\
(0.009)\end{array}$ \\
\hline $\begin{array}{l}\text { Working experience } \\
\text { (in years, linear and squ }\end{array}$ & $\begin{array}{l}-0.001 \\
(0.001)\end{array}$ & $\begin{array}{l}-0.001^{*} \\
(0.001)\end{array}$ & $\begin{array}{l}0.000 \\
(0.001)\end{array}$ \\
\hline Working intermissions & -0.000 & 0.002 & $-0.002^{*}$ \\
\hline (in years, linear and squared) & $(0.001)$ & $(0.001)$ & $(0.001)$ \\
\hline $\begin{array}{l}\text { School-leaving qualification } \\
\text { (5 dummies) }\end{array}$ & Yes $^{\star \star}$ & Yes $^{\star *}$ & Yes $^{\star \star}$ \\
\hline Family status (5 dummies) & Yes & Yes* & Yes \\
\hline
\end{tabular}




\begin{tabular}{l|rcc}
\hline $\begin{array}{l}\text { Place of residence } \\
\text { (16 "Bundesländer"dummies) }\end{array}$ & Yes** & Yes & Yes \\
\hline Professional field (54 dummies) & Yes $^{* *}$ & Yes $^{* *}$ & Yes $^{* *}$ \\
\hline Number of observations & 18,556 & 16,418 & 17,013 \\
Correctly classified & $89.4 \%$ & $94.3 \%$ & $93.7 \%$ \\
\hline
\end{tabular}

Notes: The data set used is the BIBB/BAuA Employment Survey 2006. Standard errors in brackets. ${ }^{* * *}$ indicates statistical significance at the $5 / 1 \%$ level. The numbers of changes of profession are jointly statistically significant at the $1 \%$ level in the regressions for "all" and "solo self-employed" but not statistically significant for the regression "without solo selfemployed". The numbers of different kinds of professional training are jointly statistically significant at the $1 \%$ level in all three regressions. 
Appendix Table: OLS estimates for the number of tasks and skills, controlling for firm size

\begin{tabular}{|c|c|c|c|c|c|}
\hline & $\begin{array}{l}\text { Tasks: } \\
\text { occurrence } \\
\text { sometimes } \\
\text { or often }\end{array}$ & $\begin{array}{l}\text { Tasks: } \\
\text { occurrence } \\
\text { often }\end{array}$ & $\begin{array}{l}\text { Skills: } \\
\text { total }\end{array}$ & $\begin{array}{l}\text { Skills: } \\
\text { basic }\end{array}$ & $\begin{array}{l}\text { Skills: } \\
\text { expert }\end{array}$ \\
\hline $\begin{array}{l}\text { Self-employed } \\
\text { (dummy: yes=1) }\end{array}$ & $\begin{array}{l}0.917^{* *} \\
(0.108)\end{array}$ & $\begin{array}{l}0.699^{* \star} \\
(0.092)\end{array}$ & $\begin{array}{l}0.533^{* \star} \\
(0.087)\end{array}$ & $\begin{array}{r}0.175^{*} \\
(0.080)\end{array}$ & $\begin{array}{l}0.358^{\star \star} \\
(0.073)\end{array}$ \\
\hline $\begin{array}{l}\text { Sex } \\
\text { (dummy: female=1) }\end{array}$ & $\begin{array}{l}-0.465^{\star \star} \\
(0.055)\end{array}$ & $\begin{array}{l}-0.074 \\
(0.042)\end{array}$ & $\begin{array}{l}-0.831^{* *} \\
(0.046)\end{array}$ & $\begin{array}{l}-0.378^{* *} \\
(0.041)\end{array}$ & $\begin{array}{l}-0.453^{\star *} \\
(0.034)\end{array}$ \\
\hline $\begin{array}{l}\text { Migration background } \\
\text { (dummy: yes=1) }\end{array}$ & $\begin{array}{l}-0.035 \\
(0.081)\end{array}$ & $\begin{array}{r}0.165^{*} \\
(0.067) \\
\end{array}$ & $\begin{array}{l}-0.114 \\
(0.068)\end{array}$ & $\begin{array}{l}-0.135^{\star} \\
(0.060)\end{array}$ & $\begin{array}{c}0.021 \\
(0.051)\end{array}$ \\
\hline $\begin{array}{l}\text { Highest vocational degree } \\
\text { (reference: no vocational } \\
\text { qualification): }\end{array}$ & & & & & \\
\hline $\begin{array}{l}\text { Vocational training } \\
\text { (dummy: yes }=1 \text { ) }\end{array}$ & $\begin{array}{l}0.530^{\star \star} \\
(0.089)\end{array}$ & $\begin{array}{l}0.347^{* \star} \\
(0.070)\end{array}$ & $\begin{array}{l}0.642^{* *} \\
(0.079)\end{array}$ & $\begin{array}{l}0.239^{* *} \\
(0.066)\end{array}$ & $\begin{array}{l}0.403^{* *} \\
(0.050)\end{array}$ \\
\hline $\begin{array}{l}\text { Vocational college } \\
\text { (dummy: yes=1) }\end{array}$ & $\begin{array}{l}1.428^{\star *} \\
(0.120)\end{array}$ & $\begin{array}{l}0.976^{* *} \\
(0.098)\end{array}$ & $\begin{array}{l}1.918^{\star *} \\
(0.101)\end{array}$ & $\begin{array}{l}0.667^{* *} \\
(0.089)\end{array}$ & $\begin{array}{l}1.251^{* *} \\
(0.077)\end{array}$ \\
\hline $\begin{array}{l}\text { University or } \\
\text { university of applied science } \\
\text { (dummy: } \text { yes }=1 \text { ) }\end{array}$ & $\begin{array}{l}0.294^{* *} \\
(0.100)\end{array}$ & $\begin{array}{l}0.241^{* *} \\
(0.078)\end{array}$ & $\begin{array}{l}1.482^{\star *} \\
(0.087)\end{array}$ & $\begin{array}{l}0.306^{* *} \\
(0.075)\end{array}$ & $\begin{array}{l}1.176^{* *} \\
(0.060)\end{array}$ \\
\hline $\begin{array}{l}\text { Working experience } \\
\text { (in years) }\end{array}$ & $\begin{array}{r}0.019^{*} \\
(0.007)\end{array}$ & $\begin{array}{l}0.018^{* *} \\
(0.006)\end{array}$ & $\begin{array}{l}0.029^{* *} \\
(0.006)\end{array}$ & $\begin{array}{l}0.022^{* *} \\
(0.006)\end{array}$ & $\begin{array}{c}0.008 \\
(0.005)\end{array}$ \\
\hline Working experience & $\begin{array}{l}-0.001^{* *} \\
(0000)\end{array}$ & $\begin{array}{l}-0.001^{* *} \\
(0.000)\end{array}$ & $\begin{array}{l}-0.001^{* *} \\
(0.000)\end{array}$ & $-0.001^{* *}$ & $\begin{array}{l}-0.000 \\
(0.000)\end{array}$ \\
\hline $\begin{array}{l}\text { Working intermissions } \\
\text { (in years) }\end{array}$ & $\begin{array}{c}0.001 \\
(0.014)\end{array}$ & $\begin{array}{l}-0.001 \\
(0.011)\end{array}$ & $\begin{array}{l}-0.008 \\
(0.013)\end{array}$ & $\begin{array}{l}0.011 \\
(0.012)\end{array}$ & $-0.019^{*}$ \\
\hline Working intermissions & -0.001 & -0.001 & -0.001 & -0.000 & -0.000 \\
\hline squared & $(0.001)$ & $(0.001)$ & $(0.001)$ & $(0.001)$ & $(0.000)$ \\
\hline $\begin{array}{l}\text { Tenure at current job } \\
\text { (in years) }\end{array}$ & $\begin{array}{l}0.046^{\star \star} \\
(0.008)\end{array}$ & $\begin{array}{l}0.025^{* *} \\
(0.006)\end{array}$ & $\begin{array}{c}0.011 \\
(0.007)\end{array}$ & $\begin{array}{c}0.009 \\
(0.006)\end{array}$ & $\begin{array}{c}0.002 \\
(0.005)\end{array}$ \\
\hline $\begin{array}{l}\text { Tenure at current job } \\
\text { squared }\end{array}$ & $\begin{array}{l}-0.001^{* *} \\
(0.000)\end{array}$ & $\begin{array}{l}-0.001^{* *} \\
(0.000)\end{array}$ & $\begin{array}{l}-0.000 \\
(0.000)\end{array}$ & $\begin{array}{l}-0.000 \\
(0.000)\end{array}$ & $\begin{array}{c}0.000 \\
(0.000)\end{array}$ \\
\hline $\begin{array}{l}\text { Working hours } \\
\text { (5 dummies) }\end{array}$ & Yes $^{\star *}$ & Yes $^{* *}$ & Yes $^{\star \star}$ & Yes $^{\star *}$ & Yes $^{\star \star}$ \\
\hline $\begin{array}{l}\text { Size of firm } \\
\text { (10 dummies) }\end{array}$ & Yes $^{* \star}$ & Yes $^{\star *}$ & Yes $^{* *}$ & Yes $^{* *}$ & Yes* $^{*}$ \\
\hline $\begin{array}{l}\text { Place of residence } \\
\text { (16 "Bundesländer" dummies ) }\end{array}$ & Yes & Yes $^{\star \star}$ & Yes & Yes $^{\star \star}$ & $Y_{e s}^{\star \star}$ \\
\hline $\begin{array}{l}\text { Professional field } \\
\text { (54 dummies) }\end{array}$ & Yes $^{\star *}$ & Yes $^{* *}$ & Yes $^{* *}$ & Yes $^{\star *}$ & Yes $^{* *}$ \\
\hline Constant & $\begin{array}{l}9.155^{\star *} \\
(0.270)\end{array}$ & $\begin{array}{l}4.194^{\star *} \\
(0.241)\end{array}$ & $\begin{array}{l}6.808^{* *} \\
(0.220)\end{array}$ & $\begin{array}{l}4.504^{\star *} \\
(0.192)\end{array}$ & $\begin{array}{l}2.304^{\star \star} \\
(0.180)\end{array}$ \\
\hline Number of observations & 18,401 & 18,041 & 18,375 & 18,375 & 18,375 \\
\hline $\mathrm{R}^{2}$ & 0.28 & 0.24 & 0.37 & 0.13 & 0.31 \\
\hline
\end{tabular}

Notes: The data set used is the BIBB/BAuA Employment Survey 2006. Robust standard errors in brackets. ${ }^{* * *}$ indicates statistical significance at the $5 / 1 \%$ level. 